\title{
Slow Growing Pre-Weaning Piglets Have Altered Adipokine Gene Expression
}

\author{
Tim G. Ramsay*, M. J. Stoll, T. J. Caperna \\ Animal Biosciences and Biotechnology Laboratory, Beltsville Agricultural Research Center, USDA/ARS, \\ Beltsville, USA \\ Email: ${ }^{*}$ timothy.ramsay@ars.usda.gov
}

Received 20 May 2014; revised 30 June 2014; accepted 15 July 2014

Copyright $@ 2014$ by authors and Scientific Research Publishing Inc.

This work is licensed under the Creative Commons Attribution International License (CC BY).

http://creativecommons.org/licenses/by/4.0/

(c) (i) Open Access

\begin{abstract}
Growth rate affects adipose tissue development and variations in growth rate may potentially impact adipokine expression. Samples of subcutaneous (SQ) and perirenal (PR) adipose tissues and longissimus muscle were collected at day 21 of age from the fastest and slowest growing piglets within seven litters. Reverse transcription and real-time PCR were used to quantify adipokine mRNA abundance. Leptin, adiponectin, tumor necrosis factor $\alpha$ (TNF $\alpha$ ) and lipoprotein lipase (LPL) mRNA abundance were lower in SQ from slow growing piglets (SGP) than in fast growing piglets (FGP, $P<0.05)$. Macrophage migration inhibitory factor and TNF $\alpha$ gene expression were reduced in PR from SGP in comparison to FGP $(P<0.05)$. Interleukin $1 \beta$ (IL1 $\beta)$, IL15 and LPL were increased in the longissimus of SGP relative to FGP $(P<0.05)$. Analysis of mRNA abundance for these adipokines within adipose tissue at day 21 of age demonstrated that the effect of growth rate on adipokine expression varies among different adipokines and the internal and external sites of adipose tissue deposition (PR versus SQ). The increase in longissimus expression of LPL and IL15 suggests that nutrient partitioning for energy use may be greater in the skeletal muscle of the SGP.
\end{abstract}

\section{Keywords}

Adipose Tissue, Adipokines, Neonate, Growth Rate

\section{Introduction}

The period between birth and weaning of the piglet is a time of considerable growth with a pig quadrupling in size [1] and accompanied by the rapid accumulation of adipose tissues internally and externally; proceeding from $1 \%-2 \%$ of body composition at birth to approximately $15 \%$ at weaning [2] [3]. Adipose tissue development is accompanied by the secretion of a variety of paracrine and endocrine growth factors, hormones and cy-

${ }^{*}$ Corresponding author. 
tokines, which may be called “adipokines” [4].

Previous studies have demonstrated that adipose tissue from preweaning piglets can express a variety of cytokines and respond to various in vitro or in vivo hormonal stimuli [5]-[10]. Recent work has demonstrated that intrauterine growth retardation and the inherent stress susceptibility resulting from IUGR can affect adipokine gene expression in preweaning piglets [11]. Thus, the adipokines within the neonatal adipose tissue can respond to the changing physiological demands or condition of the animal.

Growth places one of the greatest demands on the physiology of an animal. The rapid rate of preweaning growth results in linear increases in protein and fat deposition that correlates with overall growth rate [12] [13]. However, growth rate between piglets within a litter can significantly diverge [14] and slow growing piglets have been reported to display greater adiposity post-weaning [15]. The causative factors for this variation in growth rate within a litter may include differences in relative fetal maturity, health, nutrition or stress. The present study was designed to determine whether adipokine gene expression is altered in the slow growing pig relative to its littermates.

\section{Methodology}

\subsection{Animal Procedures}

Birth weights for the pigs from seven litters (Large White $\times$ Poland China $\times$ Landrace) were recorded and subsequently weights were recorded three days a week (Monday, Wednesday, Friday) until day 21 of age when a final weight was recorded. Body weight changes were plotted and sex matched pairs of littermate pigs (six pairs of females, one pair of males) were selected based upon a divergence in growth rate $\geq 50 \mathrm{~g} /$ day. These seven pairs of littermate pigs were obtained from seven different sows. Birth weights of selected pigs were within 1 standard deviation of the mean litter birth weight to avoid using small for gestational age pigs. Pigs selected for this study were observed to be healthy with no indications of less than optimal health.

On day 21 of age, pairs were euthanized by intravenous pentobarbital sodium (200 mg/kg) administration between 0900 - 1100 hours while animals were in the fed state. Tissue samples were then collected. Animal handling and euthanasia procedures were approved by the USDA-ARS Beltsville Area animal care and use committee.

Dorsal subcutaneous (SQ) adipose tissue samples were collected between the second and fourth thoracic vertebrae while perirenal (PR) adipose tissue was collected from around both kidneys. A sample of longissimus muscle was also collected from the region between the first and third lumbar vertebrae. Tissues were diced and frozen in liquid nitrogen immediately upon removal from the carcass and stored at $-80^{\circ} \mathrm{C}$. Duplicate tissue samples (100 mg) in Qiasol extraction solution (Qiagen, Valencia, CA) were disrupted using a tissue homogenizer and total RNA was isolated using Qiagen RNeasy spin columns according to the manufacturer's protocol (Qiagen). Integrity of RNA was assessed via agarose gel electrophoresis and RNA concentration was determined spectrophotometrically using A260 and A280 measurements. Following verification of RNA integrity, total RNA from the duplicate tissue samples was pooled for each pig prior to reverse transcription (RT) and real-time PCR analysis.

\subsection{Real-Time PCR Analysis}

The adipokine genes selected for analysis included leptin, adiponectin, tumor necrosis factor $\alpha$ (TNF $\alpha$ ), interleukin $1 \beta$ (IL1 $\beta$ ), IL6, IL15, macrophage migration inhibitory factor (MIF) and monocyte chemotactic protein, also known as chemokine (C-C motif) ligand 2 (CCL2). These genes were selected as they all have been demonstrated to be expressed by adipose tissue from swine, as previously described in the Introduction, and their ontogeny of development in neonatal adipose tissue has been characterized [10]. Leptin, adiponectin, lipoprotein lipase (LPL) and fatty acid synthase (FAS) were selected because they are markers for adipose differentiation in swine [16]. The interleukins $1 \beta, 6$ and 15 were included because they have been identified by Hausman et al. [9] to be expressed by neonatal pig adipose tissue using proteomic analysis. Tumor necrosis factor $\alpha$ was examined as it has been the most characterized of all adipokines and has key regulatory roles in the expression of a variety of proteins, including the adipokines MIF and CCL2, which were included in this study. Insulin-like growth factor 1 (IGF1) was selected as it has been shown to be a potent adipokine expressed within adipose tissue [5]. Cyclophilin A is a housekeeping gene that was used as a relative standard for comparisons [17]. The primers 
used for generating the amplicons have been previously reported [10] [11] [18]. All primer sets were designed to span an intron.

Thermal cycling and data acquisition were performed with a Bio-Rad iCycler IQ system (Bio-Rad Laboratories Inc., Hercules, CA). Reverse transcription and real time PCR analysis were performed in a two tube assay. Reverse transcription was performed in duplicate using a Superscript First-Strand Synthesis System for RT-PCR kit (Invitrogen, Carlsbad, CA) according to the manufacturer's recommendations, as previously described [10].

Real time PCR was done in duplicate using the IQ Sybr Green Supermix kit (Bio-Rad) for each duplicate of tissue. A $24 \mu \mathrm{L}$ reaction mix was made containing $12.5 \mu \mathrm{L}$ sybr green supermix, $1.0 \mu \mathrm{L}$ forward primer $(10 \mu \mathrm{M})$, $1.0 \mu \mathrm{L}$ reverse primer $(10 \mu \mathrm{M})$ and $9.5 \mu \mathrm{L}$ sterile water. This reaction mix was added to each well, followed by $1.0 \mu \mathrm{L}$ RT product ( $25 \mu \mathrm{L}$ total volume).

Parameters for all reactions except cyclophilin were as follows: 1 cycle $95^{\circ} \mathrm{C}$ for $15 \mathrm{~min}$ (PCR activation), followed by 30 cycles, $94^{\circ} \mathrm{C}$ for $15 \mathrm{~s}, 58^{\circ} \mathrm{C}$ for $30 \mathrm{~s}, 72^{\circ} \mathrm{C}$ for $30 \mathrm{~s}$, with a final extension at $72^{\circ} \mathrm{C}$ for $8 \mathrm{~min}$. Parameters for cyclophilin were as follows: 1 cycle $95^{\circ} \mathrm{C}$ for $15 \mathrm{~min}$ (PCR activation), followed by 30 cycles, $94^{\circ} \mathrm{C}$ for $30 \mathrm{~s}, 55^{\circ} \mathrm{C}$ for $30 \mathrm{~s}, 72^{\circ} \mathrm{C}$ for $30 \mathrm{~s}$, with a final extension at $72^{\circ} \mathrm{C}$ for $7 \mathrm{~min}$. Melting curve analysis was performed on all real time PCR reactions to confirm specificity and identity of the real time PCR products. A non-template control was run for every assay. Specificity of real time PCR products was further confirmed by agarose gel electrophoresis. The two-step real time PCR reactions were optimized for linearity (exponential amplification) from $>20$ to $<30$ cycles under the conditions described above.

\subsection{Quantification of mRNA Abundance.}

At the end of the PCR, baseline and threshold crossing values (CT) for all analyzed genes were calculated using the BioRad software and the CT values were exported to Microsoft Excel for analysis. The $\Delta \Delta C T$ method was used to perform relative comparisons in mRNA abundance [19] [20]. The transcription level of the genes of interest relative to the amount of cyclophilin A mRNA was calculated. These data were then compared to expression in a randomly selected piglet to standardize the results and the logarithms calculated as described for the $\Delta \Delta \mathrm{CT}$ method. Values are presented as the mean \pm SEM of duplicate determinations from tissues from all animals in each group $(n=7)$.

\subsection{Statistical Analysis.}

Paired t-test was used to compare gene transcription level within each pair of slow and fast growing piglets with Sigma Stat software (SPSS Science, Chicago, IL). Means were defined as different at $\mathrm{P}<0.05$.

\section{Results}

Birth weights did not differ between fast and slow growing piglets ( $\mathrm{P}>0.05$, Table 1 ). Litter size varied from 8

\begin{tabular}{|ccc|}
\hline Table 1. Animal performance. & \multicolumn{2}{c}{ Growth Rate } \\
\hline Parameter & Low & High \\
\hline Birth Weight (kg) & 1.53 & 1.63 \\
& $(0.07)$ & $(0.06)$ \\
Day 21 Weight (kg) & $4.89^{*}$ & 6.60 \\
& $(0.22)$ & $(0.28)$ \\
Total Gain (kg) & $3.36^{*}$ & 4.97 \\
& $(0.19)$ & $(0.26)$ \\
Average Daily Gain (gm/day) & $161^{*}$ & 237 \\
& $(9)$ & $(12)$
\end{tabular}
* Significantly different from piglets with high growth rate $(\mathrm{P}<0.05, \mathrm{n}=7)$. Data are
represented by means with standard errors in parentheses. 
to 13 pigs per litter with an average of $9.9 \pm 0.7$. Fast growing piglets weighed $1.61 \pm 0.19 \mathrm{~kg}$ more at day 21 than slow growing piglets $(\mathrm{P}<0.001)$. The litters average daily gain was $210 \pm 7 \mathrm{~g} / \mathrm{day}$, while fast growing piglets gained an additional $28 \pm 11 \mathrm{~g}$ /day $(+13.3 \%$; $\mathrm{P}>0.05)$ and slow growing piglets gained $49 \pm 9 \mathrm{~g}$ less per day $(-24.4 \%, \mathrm{P}<0.001)$ than the rest of the litter. The difference in average daily gain between fast and slow growing piglets was $77 \pm 9 \mathrm{~g}(\mathrm{P}<0.001)$.

Among the adipokines (Figure 1), leptin was $43 \%$ lower in the SQ adipose of slow growing piglets than fast growing piglets $(\mathrm{P}<0.05$, Figure $1(\mathrm{a}))$ while $\mathrm{PR}$ leptin mRNA abundance was not affected by growth rate $(\mathrm{P}>$ $0.05)$. Adiponectin gene expression was reduced by $36 \%$ in SQ of the slow growing piglet versus the fast growing piglet $(\mathrm{P}<0.01$, Figure $1(\mathrm{~b}))$. Perirenal and longissimus mRNA abundance were similar between slow and fast growing piglets $(\mathrm{P}>0.05)$. Tumor necrosis factor $\alpha$ gene expression was reduced by $36 \%$ in SQ and $40 \%$ in $\mathrm{PR}$ of slow growing piglets relative to fast growing piglets $(\mathrm{P}<0.05$, Figure $1(\mathrm{c})$ ). The mRNA abundance of MIF was reduced by $56 \%$ in $\mathrm{PR}$ of slow growing piglets in comparison to tissue from fast growing piglets $(\mathrm{P}<$ 0.02 , Figure $1(\mathrm{~d})$ ), whereas both SQ and longissimus MIF steady state concentrations were unaffected by growth rate ( $\mathrm{P}>0.05)$. The mRNA abundance of IL1 $\beta$ was increased by $57 \%$ in longissimus of slow growing piglets relative to fast growing piglets $(\mathrm{P}<0.02$, Figure $1(\mathrm{e})$ ) while IL15 gene expression was increased in longissimus by $47 \%(\mathrm{P}<0.01$, Figure $1(\mathrm{f})$ ). Adipose tissue expression of either of these adipokines was not altered by growth rate $(\mathrm{P}>0.05)$. No differences in mRNA abundance were detected for the remaining adipokines that were examined (IL6, CCL2 and IGF1) between tissues of fast and slow growing piglets ( $\mathrm{P}>0.05$; data not presented).

Gene expression of the enzyme LPL was reduced by $24 \%$ in SQ $(P<0.05)$ while increased by $71 \%$ in longissimus $(\mathrm{P}<0.01)$ of slow growing pigs, relative to fast growing piglets (Figure 2(a)). The mRNA abundance for FASN was not affected by growth rate $(\mathrm{P}>0.05$; Figure $2(\mathrm{~b}))$.

\section{Discussion}

Numerous studies have described the expression of adipokines in adult animals and humans [4] [21]. Hausman et al. [9] have previous reported that 5 - 7 day old pig adipose tissue expresses a variety of adipokines. However, the present study is the first attempt to examine the relationship of growth rate and adipokine expression within adipose tissue in vivo during the preweaning period. The neonatal period is characterized by rapid growth rates
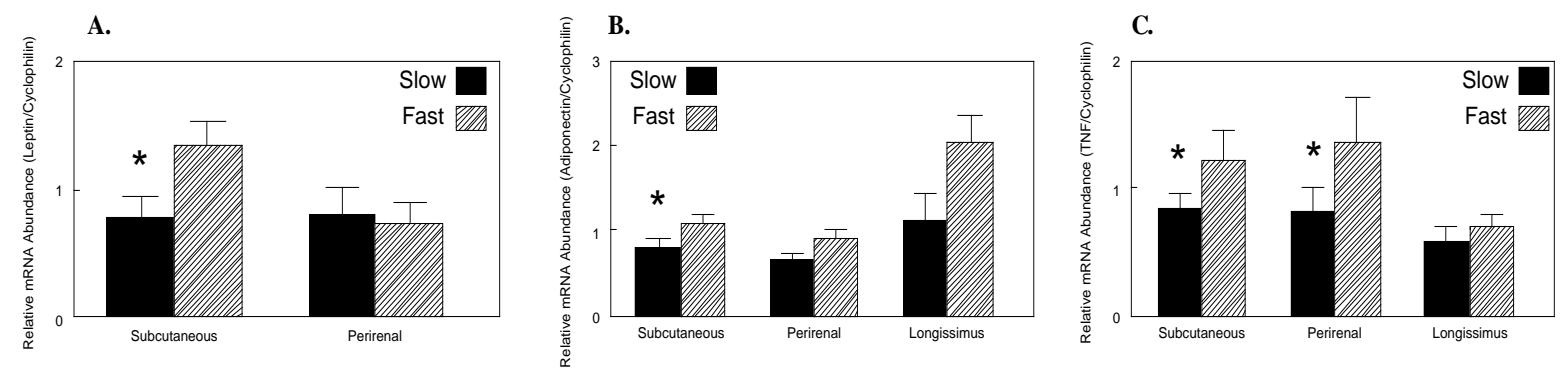

D.

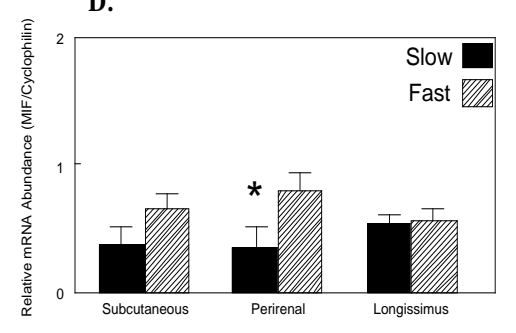

E.

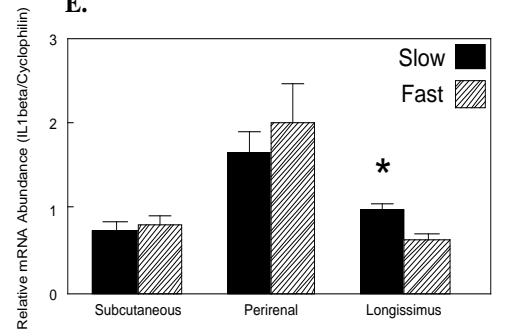

F.

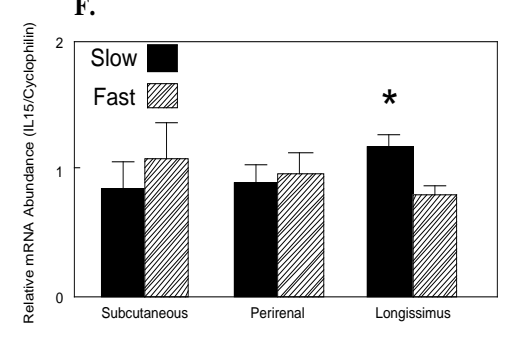

Figure 1. Relative adipokine mRNA abundance in slow and fast growing piglets. Leptin (Figure 1(A)), adiponectin (Figure 1(B)), TNF $\alpha$ (Figure 1(C)), MIF (Figure 1(D)), IL1 $\beta$ (Figure 1(E)) and IL15 (Figure 1(F)) expression in subcutaneous or perirenal adipose tissues or longissimus muscle from slow and fast growing piglets at day 21 of age $(n=7)$. Reverse transcription and real time PCR was then performed as described in the methodology. Data are expressed relative to cyclophilin A expression in each tissue sample. "Different from tissue of the fast growing piglets using paired t-test between slow and fast growing littermates $(\mathrm{P}<0.05)$. 
A.

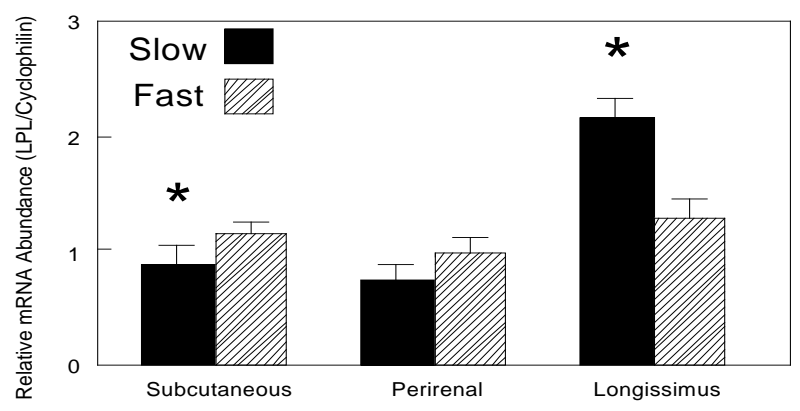

B.

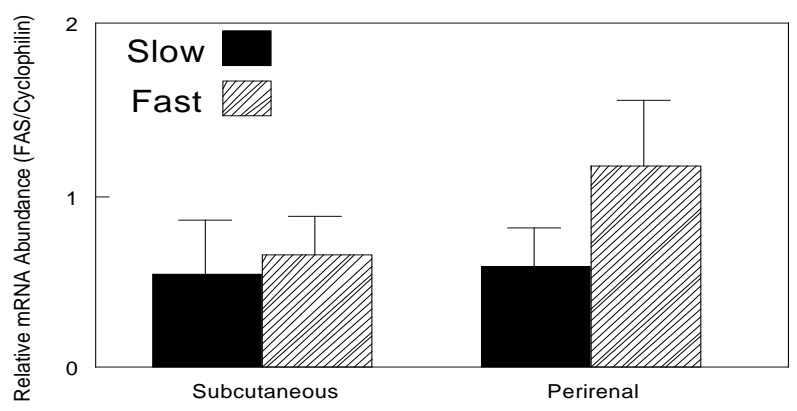

Figure 2. Relative enzyme mRNA abundance in slow and fast growing piglets. Lipoprotein lipase (LPL, Figure 2(A)) and fatty acid synthase (FASN, Figure 2(B)) expression in subcutaneous or perirenal (PR) adipose tissues or longissimus muscle from slow and fast growing piglets at day 21 of age $(\mathrm{n}=$ 7). Data are expressed relative to cyclophilin A expression in each tissue sample. *Different from tissue of the fast growing piglets using paired t-test between slow and fast growing littermates $(\mathrm{P}<0.05)$.

that are paralleled by rapid accumulation of lipid within newly formed adipocytes and the differentiation of preadipocytes into adipocytes [1] [12] [22] [23]. Slower growing and subsequently smaller piglets have less fat deposition during the preweaning period [12] [13]. This slower growth rate may be the consequence a difference in relative fetal maturity, health status, nutrition, response to stress or a combination of these factors.

The majority of adipose tissue deposition in swine is subcutaneous and this is reflected in the accumulation of SQ LPL mRNA in the present study, which is a marker for adipocyte differentiation and lipid metabolism [16] [24] [25]. Slower growing piglets had less SQ LPL mRNA abundance than fast growing piglets. Leptin and adiponectin mRNA abundance were also lower in the SQ of the slower growing piglets. Both genes are expressed almost exclusively within the adipocyte in swine [26] [27]. Thus the smaller abundance of SQ leptin, adiponectin and LPL mRNA by the SQ adipose tissue of the slow growing piglet during the first 21 days of life may reflect lower rates of lipid accumulation. Dual x-ray absorptiometry of additional pairs of pigs from other litters within this herd has confirmed that slower growing piglets have lower rates of lipid deposition than faster growing piglets [13]. This lower rate of fat deposition and change in gene expression could be the consequence of a reduced nutrient intake by the slow growing pig. Dietary restriction has been demonstrated to reduce adipose tissue expression of leptin [28] [29] and LPL [29] [30]. However, adiponectin mRNA abundance is increased with dietary restriction [31] [32], while it was depressed in this study, suggesting intake was not reduced in slow growing pigs. In addition, the runt pig has a poor growth rate and suffers from an inability to compete for nutrition with its much larger littermates, yet no differences in the expression of any of these three genes was observed at 21 days of age between runt and normal growing littermates [11]. Unfortunately, dietary intake was not measured in the present study.

These changes in the SQ were not accompanied by similar changes in the PR. This may reflect the later development of the depot or unique differences between the two sites of deposition. Previous studies have reported differential gene expression by the SQ and PR in the neonatal pig [10] [11]. Numerous studies have documented 
the intrinsic differences in the development, physiology and metabolism between internal and external sites of adipose tissue deposition of swine [2] [33]-[35]. The physiological and metabolic demands of growth may produce developmental changes that cause internal and external sites of adipose tissue deposition to respond differently.

Tumor necrosis factor $\alpha$ has been the most thoroughly evaluated adipokine; TNF $\alpha$ can promote lipolysis, suppress lipogenesis and inhibit lipid uptake by adipose tissue [36] [37]. Differences in growth rate had an impact on TNF $\alpha$ mRNA abundance in both sites of adipose tissue deposition unlike LPL, leptin or adiponectin. Pigs with lower growth rates had lower TNF $\alpha$ mRNA abundance than pigs with higher growth rates. This parallels the reported effects of dietary restriction on adipose TNF $\alpha$ mRNA abundance [38] and would imply the slower growing piglet cannot compete for nutrition from the sow. However, no difference in adipose TNF $\alpha$ mRNA abundance was observed in adipose tissues of slow growing, poorly competitive runt pigs relative to normal growing littermates [11]. The observed differences in TNF $\alpha$ gene expression in the present study suggest that TNF $\alpha$ may be counter regulatory to the metabolic activity of the tissue. Previously Mitchell et al. [13], using comparable pigs, demonstrated that the slow growing pigs had reduced lipid accumulation; thus suggesting that the consequences of lowering TNF $\alpha$ expression in those slower growing pigs may be to alter lipid accumulation and the partitioning of energy between adipose tissue and muscle.

Macrophage migration inhibitory factor was the only gene that demonstrated a difference in transcript level between slow and fast growing piglets exclusively in PR. The MIF mRNA abundance was much lower in the PR from slow than fast growing piglets. This is the opposite of what was observed in runt pigs at day 21 of age relative to average weight littermates. Expression of MIF is responsive to glucose and insulin status of the adipocyte [39] [40]. The MIF protein has been shown to both impair glucose uptake by the adipocyte and attenuate insulin sensitivity [41]. The consequences of the lower MIF mRNA abundance in the slow growing piglet would imply a paracrine counter regulatory attempt to increase the lower lipid accretion rate of the slow growing pig [12] [13]. However, MIF has numerous other functions that have yet to be evaluated within the context of adipose tissue biology [42].

Contrary to the reduction in mRNA abundance for LPL in adipose tissue, gene expression was elevated in the longissimus muscle of the slow growing piglet. Lipoprotein lipase is an essential enzyme for the uptake and metabolism of fatty acids by skeletal muscle [43]. The increased LPL mRNA abundance in the slower growing piglet may imply an increased partitioning of lipid substrates to the skeletal muscle of the slower growing piglet, potentially in response to a lower feed intake. Restricted feed intake has been shown to elevate skeletal muscle LPL activity [44]. Slower growing piglets have been reported to have higher rates of lean deposition [12]. Dual x-ray absorptiometry of additional slow and fast growing pairs of pigs from other litters at our laboratory has confirmed that slower growing piglets have higher rates of lean deposition than faster growing piglets [13]. Thus the energy derived from lipid uptake by the skeletal muscle through the actions of LPL may be used for protein accretion.

Interleukin $1 \beta$ has been reported to reduce muscle protein synthesis [45] and to reduce $\alpha$-amino isobutyrate uptake [46], indicative of a reduction in amino acid uptake, when injected into rats. However, these effects appear to be indirect and it has been proposed that IL1 $\beta$ only serves as a mediator [46]. The direct and specific actions of IL1 $\beta$ on skeletal muscle metabolism or growth have not been defined. The increase in IL1 $\beta$ mRNA abundance in the longissimus of the slower growing piglet relative to the fast growing piglet would imply an increase in protein breakdown, but since the slower growing pig has a higher rate of protein accretion [12] [13], that would imply that overall protein turnover is increased in the smaller piglet versus the larger piglet. This would require validation with in vivo protein turnover experiments.

Interleukin 15 is highly expressed by skeletal muscle cells [47] and secreted [48]. The protein has been demonstrated to reduce protein breakdown [49] [50] and to stimulate muscle glucose uptake and lipid oxidation ([51] [52]. The greater IL15 gene expression in the slower growing piglet relative to the faster growing piglet suggests that this protein may be functioning to enhance energy utilization and protein deposition rates in the slower growing piglet. Dunshea et al. [12] and Mitchell et al. [2012] have reported that slower growing piglets have higher protein accretion rates in support of this hypothesis.

\section{Conclusion}

Previous studies have reported that slower growing piglets have reduced lipid accretion rates relative to their faster growing littermates, when comparing pigs born at similar birth weights. The present study supports those 
studies with the observation of reduced mRNA abundance for LPL, leptin and adiponectin expression in SQ adipose tissue from slow growing pigs relative to their faster growing littermates, suggestive of lower lipid accumulation within the adipose tissue. These changes seen in the SQ adipose tissue were not observed in the PR adipose tissue, indicative of developmental differences between the two sites of fat deposition. Limited effects of differential growth rates were seen for several of the adipokines analyzed; however, a reduction in TNF $\alpha$ mRNA abundance in the SQ adipose tissue may be a compensatory mechanism in response to the lower lipid accumulation rates reported for slower growing pigs. While an increase in muscle, IL- $1 \beta$ may be suggestive of an increase in protein turnover in the slow growing pig relative to the faster growing sibling. The increase in IL15 gene expression in association with an increase in LPL mRNA suggests skeletal muscle energy utilization and protein depositions are elevated in slow growing pigs; in agreement with the reported higher protein accretion rates of slower growing pigs.

\section{Acknowledgements}

The authors thank A. Shannon for her assistance with animal collection. The authors also thank the swine herd staff, USDA-Beltsville, for their work in animal care.

\section{References}

[1] Beaulieu, A.D., Aalhus, J.L., Williams, N.H. and Patience, J.F. (2010) Impact of Piglet Birth Weight, Birth Order and Litter Size on Subsequent Growth Performance, Carcass Quality, Muscle Composition and Eating Quality of Pork. Journal of Animal Science, 88, 2767-2778. http://dx.doi.org/10.2527/jas.2009-2222

[2] Anderson, D.B. and Kauffman, R.G. (1973) Cellular and Enzymatic Changes in Porcine Adipose Tissue during Growth. Journal of Lipid Research, 14, 160-168.

[3] Mersmann, H.J., Goodman, J.R. and Brown, L.J. (1975). Development of Swine Adipose Tissue: Morphology and Chemical Composition. Journal of Lipid Research, 16, 269-279.

[4] Trayhurn, P., Bing, C. and Wood, I.S. (2006) Adipose Tissue and Adipokines-Energy Regulation from the Human Perspective. Journal of Nutrition, 136, 1935S-1939S.

[5] Gaskins, H.R., Kim, J.W., Wright, J.T., Rund, L.A. and Hausman, G.J. (1990) Regulation of Insulin-Like Growth Factor-I Ribonucleic Acid Expression, Polypeptide Secretion, and Binding Protein Activity by Growth Hormone in Porcine Preadipocyte Cultures. Endocrinology, 126, 622-630. http://dx.doi.org/10.1210/endo-126-1-622

[6] Tchoukalova, Y.D., Grider, A., Mouat, M.F. and Hausman, G.J. (2000) Priming with Magnesium-Deficient Media Inhibits Preadipocyte Differentiation via Potential Upregulation of Tumor Necrosis Factor-Alpha. Biological Trace Element Research, 74, 11-21. http://dx.doi.org/10.1385/BTER:74:1:11

[7] Hausman, G.J., Richardson, R.L. and Simmen, F.A. (2002) Secretion of Insulin-Like Growth Factor (IGF)-I and -II and IGF Binding Proteins (IGFBPs) in Fetal Stromal-Vascular (S-V) Cell Cultures Obtained before and after the Onset of Adipogenesis in Vivo. Growth Development and Aging, 66, 11-26.

[8] Mostyn, A., Litten, J.C., Perkins, K.S., Euden, P.J., Corson, A.M., Symonds, M.E. and Clarke, L. (2005) Influence of Size at Birth on the Endocrine Profiles and Expression of Uncoupling Proteins in Subcutaneous Adipose Tissue, Lung, and Muscle of Neonatal Pigs. American Journal of Physiology, 288, R1536-R1542. http://dx.doi.org/10.1152/ajpregu.00423.2004

[9] Hausman, G.J., Poulos, S.P., Richardson, R.L., Barb, C.R., Andacht, T., Kirk, H.C. and Mynatt, R.L. (2006) Secreted Proteins and Genes in Fetal and Neonatal Pig Adipose Tissue and Stromal-Vascular Cells. Journal of Animal Science, 84, 1666-1681. http://dx.doi.org/10.2527/jas.2005-539

[10] Ramsay, T.G. and Caperna, T.J. (2009) Ontogeny of Adipokine Expression in Neonatal Pig Adipose Tissue. Comparative Biochemistry and Physiology B, 152, 72-78. http://dx.doi.org/10.1016/j.cbpb.2008.09.088

[11] Ramsay, T.G., Stoll, M.J. and Caperna, T.J. (2010b) Adipokine Gene Transcription Level in Adipose Tissue of Runt Piglets. Comparative Biochemistry and Physiology B, 155, 97-105. http://dx.doi.org/10.1016/j.cbpb.2009.09.006

[12] Dunshea, F.R., Suster, D., Kerton, D.J. and Leury, B.J. (2003) Exogenous Porcine Somatotropin Administered to Neonatal Pigs at High Doses Can Alter Lifetime Fat but Not Lean Tissue Deposition. British Journal of Nutrition, 89, 795801. http://dx.doi.org/10.1079/BJN2003843

[13] Mitchell, A.D., Ramsay, T.G., Caperna, T.J. and Scholz, A.M. (2012) Body Composition of Piglets Exhibiting Different Growth Rates. Archives of Animal Breeding, 55, 356-363.

[14] Milligan, B.N., Fraser, D. and Kramer, D.L. (2002) Within-Litter Birth Weight Variation in the Domestic Pig and Its Relation to Pre-Weaning Survival, Weight Gain, and Variation in Weaning Weights. Livestock Production Science, 76, 
181-191. http://dx.doi.org/10.1016/S0301-6226(02)00012-X

[15] Mahan, D.C. and Lepine, A.J. (1991) Effect of Pig Weaning Weight and Associated Nursery Feeding Programs on Subsequent Performance to 105 Kilograms Body Weight. Journal of Animal Science, 69, 1370-1378.

[16] McNeel, R.L., Ding, S.T., Smith, E.O. and Mersmann, H.J. (2000) Effect of Feed Restriction on Adipose Tissue Transcript Concentrations in Genetically Lean and Obese Pigs. Journal of Animal Science, 78, 934-942.

[17] Choi, I.S., Collisson, E.W., Maheswaran, S.K. and Yoo, H.S. (2002) Evaluation of Cytokine Gene Expression in Porcine Spleen Cells, Peripheral Blood Mononuclear Cells, and Alveolar Macrophages by Competitive RT-PCR. FEMS Immunololgy and Medical Microbiology, 34, 119-126. http://dx.doi.org/10.1111/j.1574-695X.2002.tb00612.X

[18] Ramsay T.G., Richards, M.P., Li, C.J. and Caperna, T.J. (2010) IGF-I Mediated Inhibition of Leptin Receptor Expression in Porcine Hepatocytes. Comparative Biochemistry and Physiology B, 155, 43-48. http://dx.doi.org/10.1016/j.cbpb.2009.09.007

[19] Winer, J., Jung, C.K., Shackel, I. and Williams, P.M. (1999) Development and Validation of Real-Time Quantitative Reverse Transcriptase-Polymerase Chain Reaction for Monitoring Gene Expression in Cardiac Myocytes in Vitro. Analytical Biochemistry, 270, 41-49. http://dx.doi.org/10.1006/abio.1999.4085

[20] Livak, K.J. and Schmittgen, T.D. (2001) Analysis of Relative Gene Expression Data Using Real-Time Quantitative PCR and the 2(-Delta Delta C(T)) Method. Methods, 25, 402-408. http://dx.doi.org/10.1006/meth.2001.1262

[21] Trayhurn, P. and Wood, I.S. (2004) Adipokines: Inflammation and the Pleiotropic Role of White Adipose Tissue. British Journal of Nutrition, 92, 347-355. http://dx.doi.org/10.1079/BJN20041213

[22] Martin, R.J., Ramsay, T. and Hausman, G.J. (1984) Adipocyte Development. Pediatric Annals, 13, 448-453.

[23] Herrera, E. and Amusquivar, E. (2000) Lipid Metabolism in the Fetus and the Newborn. Diabetes/Metabolism Research and Reviews, 16, 202-210. http://dx.doi.org/10.1002/1520-7560(200005/06)16:3<202::AID-DMRR116>3.0.CO;2-\#

[24] Ailhaud, G. (1996) Early Adipocyte Differentiation. Biochemical Society Transactions 24, 400-402.

[25] Ding, S.T., McNeel, R.L. and Mersmann, H.J. (1999) Expression of Porcine Adipocyte Transcripts: Tissue Distribution and Differentiation in Vitro and in Vivo. Comparative Biochemistry and Physiology B, 123, 307-318. http://dx.doi.org/10.1016/S0305-0491(99)00077-2

[26] Chen, X., Hausman, D.B., Dean, R.G. and Hausman, G.J. (1997) Differentiation-Dependent Expression of Obese (OB) Gene by Preadipocytes and Adipocytes in Primary Cultures of Porcine Stromal-Vascular Cells. Biochimica Biophysica Acta, 1359, 136-142. http://dx.doi.org/10.1016/S0167-4889(97)00083-9

[27] Lord, E., Ledoux, S., Murphy, B.D., Beaudry, D. and Palin, M.F. (2005) Expression of Adiponectin and Its Receptors in Swine. Journal of Animal Science, 83, 565-578.

[28] Scarpace, P.J., Nicolson, M. and Matheny, M. (1998) UCP2, UCP3 and Leptin Gene Expression: Modulation by Food Restriction and Leptin. Journal of Endocrinology, 159, 349-357. http://dx.doi.org/10.1677/joe.0.1590349

[29] Viguerie, N., Vidal, H., Arner, P., Holst, C., Verdich, C., Avizou, S., Astrup, A., Saris, W.H., Macdonald, I.A., Klimcakova, E., Clément, K., Martinez, A., Hoffstedt, J., Sørensen, T.I. and Langin, D. (2005) Adipose Tissue Gene Expression in Obese Subjects during Low-Fat and High-Fat Hypocaloric Diets. Diabetologia, 48, 123-131. http://dx.doi.org/10.1007/s00125-004-1618-X

[30] Sugden, M.C., Grimshaw, R.M., Lall, H. and Holness, M.J. (1994) Regional Variations in Metabolic Responses of White Adipose Tissue to Food Restriction. American Journal of Physiology, 267, E892-E899.

[31] Niemann, B., Silber, R.E. and Rohrbach, S. (2008) Age-Specific Effects of Short- and Long-Term Caloric Restriction on the Expression of Adiponectin and Adiponectin Receptors: Influence of Intensity of Food Restriction. Experimental Gerontology, 43, 706-713. http://dx.doi.org/10.1016/j.exger.2008.02.008

[32] Turyn, J., Korczynska, J., Presler, M., Stelmanska, E., Goyke, E. and Swierczynski, J. (2008) Up-Regulation of Rat Adipose Tissue Adiponectin Gene Expression by Long-Term but Not by Short-Term Food Restriction. Molecular and Cellular Biochemistry, 312, 185-191. http://dx.doi.org/10.1007/s11010-008-9733-5

[33] Anderson, D.B., Kauffman, R.G. and Kastenschmidt, L.L. (1972) Lipogenic Enzyme Activities and Cellularity of Porcine Adipose Tissue from Various Anatomical Locations. Journal of Lipid Research, 13, 593-599.

[34] Budd, T.J., Atkinson, J.L., Buttery, P.J., Salter, A.M. and Wiseman, J. (1994) Effect of Insulin and Isoproterenol on Lipid Metabolism in Porcine Adipose Tissue from Different Depots. Comparative Biochemistry and Physiology. Pharmacology, Toxicology and Endocrinology, 108, 137-143.

[35] Gardan, D., Gondret, F. and Louveau, I. (2006) Lipid Metabolism and Secretory Function of Porcine Intramuscular Adipocytes Compared with Subcutaneous and Perirenal Adipocytes. American Journal of Physiology, 291, E372-E380. http://dx.doi.org/10.1152/ajpendo.00482.2005 
[36] Price, S.R., Olivecrona, T. and Pekala, P.H. (1986) Regulation of Lipoprotein Lipase Synthesis by Recombinant Tumor Necrosis Factor-The Primary Regulatory Role of the Hormone in 3T3-L1 Adipocytes. Archives of Biochemistry and Biophysics, 251, 738-746. http://dx.doi.org/10.1016/0003-9861(86)90384-X

[37] Ruan, H. and Lodish, H.F. (2003) Insulin Resistance in Adipose Tissue: Direct and Indirect Effects of Tumor Necrosis Factor- $\alpha$. Cytokine \& Growth Factor Reviews, 14, 447-455. http://dx.doi.org/10.1016/S1359-6101(03)00052-2

[38] Sherman, H., Frumin, I., Gutman, R., Chapnik, N., Lorentz, A., Meylan, J., le Coutre, J. and Froy, O. (2011) LongTerm Restricted Feeding Alters Circadian Expression and Reduces the Level of Inflammatory and Disease Markers. Journal of Cellular and Molecular Medicine, 15, 2745-2759. http://dx.doi.org/10.1111/j.1582-4934.2010.01160.X

[39] Sakaue, S., Nishihira, J., Hirokawa, J., Yoshimura, H., Honda, T., Aoki, K., Tagami, S. and Kawakami, Y. (1999) Regulation of Macrophage Migration Inhibitory Factor (MIF) Expression by Glucose and Insulin in Adipocytes in Vitro. Molecular Medicine, 5, 361-371.

[40] Atsumi, T., Cho, Y.R., Leng, L., McDonald, C., Yu, T., Danton, C., Hong, E.G., Mitchell, R.A., Metz, C., Niwa, H., Takeuchi, J., Onodera, S., Umino, T., Yoshioka, N., Koike, T., Kim, J.K. and Bucala, R. (2007) The Proinflammatory Cytokine Macrophage Migration Inhibitory Factor Regulates Glucose Metabolism during Systemic Inflammation. Journal of Immunology, 179, 5399-5406. http://dx.doi.org/10.4049/jimmunol.179.8.5399

[41] Toso, C., Emamaullee, J.A., Merani, S. and Shapiro, A.M. (2008) The Role of Macrophage Migration Inhibitory Factor on Glucose Metabolism and Diabetes. Diabetologia, 51, 1937-1946. http://dx.doi.org/10.1007/s00125-008-1063-3

[42] Hoi, A.Y., Iskander, M.N. and Morand, E.F. (2007) Macrophage Migration Inhibitory Factor: A Therapeutic Target across Inflammatory Diseases. Inflammation \& Allergy Drug Targets, 6, 183-190. http://dx.doi.org/10.2174/187152807781696455

[43] Wang, H. and Eckel, R.H. (2009) Lipoprotein Lipase: From Gene to Obesity. American Journal of Physiology, 297, E271-E288. http://dx.doi.org/10.1152/ajpendo.90920.2008

[44] Taskinen, M.R. and Nikkilä, E.A. (1979) Effects of Caloric Restriction on Lipid Metabolism in Man: Changes of Tissue Lipoprotein Lipase Activities and of Serum Lipoproteins. Atherosclerosis, 32, 289-299. http://dx.doi.org/10.1016/0021-9150(79)90172-2

[45] Ballmer, P.E., McNurlan, M.A., Southorn, B.G., Grant, I. and Garlick, P.J. (1991) Effects of Human Recombinant Interleukin-1 Beta on Protein Synthesis in Rat Tissues Compared with a Classical Acute-Phase Reaction Induced by Turpentine. Rapid Response of Muscle to Interleukin-1 Beta. Biochemical Journal, 279, 683-688.

[46] Argilés, J.M., López-Soriano, F.J., Wiggins, D. and Williamson, D.H. (1989) Comparative Effects of Tumour Necrosis Factor-Alpha (cachectin), Interleukin-1-Beta and Tumour Growth on Amino Acid Metabolism in the Rat in Vivo. Absorption and Tissue Uptake of Alpha-Amino[1-14C]isobutyrate. Biochemical Journal, 261, 357-362.

[47] Quinn, L.S., Strait-Bodey, L., Anderson, B.G., Argilés, J.M. and Havel, P.J. (2005) Interleukin-15 Stimulates Adiponectin Secretion by 3T3-L1 Adipocytes: Evidence for a Skeletal Muscle-to-Fat Signaling Pathway. Cell Biology International, 29, 449-457. http://dx.doi.org/10.1016/j.cellbi.2005.02.005

[48] Tagaya, Y., Kurys, G., Thies, T.A., Losi, J.M., Azimi, N., Hanover, J.A., Bamford, R.N. and Waldmann, T.A. (1997) Generation of Secretable and Nonsecretable Interleukin 15 Isoforms through Alternate Usage of Signal Peptides. Proceedings of the National Academy of Sciences of the United States of America, 94, 14444-14449. http://dx.doi.org/10.1073/pnas.94.26.14444

[49] Carbó, N., López-Soriano, J., Costelli, P., Busquets, S., Alvarez, B., Baccino, F.M., Quinn, L.S., López-Soriano, F.J. and Argilés, J.M. (2000) Interleukin-15 Antagonizes Muscle Protein Waste in Tumour-Bearing Rats. British Journal of Cancer, 83, 526-531. http://dx.doi.org/10.1054/bjoc.2000.1299

[50] Busquets, S., Figueras, M.T., Meijsing, S., Carbó, N., Quinn, L.S., Almendro, V., Argilés, J.M. and López-Soriano, F.J. (2005) Interleukin-15 Decreases Proteolysis in Skeletal Muscle: A Direct Effect. International Journal of Molecular Medicine, 16, 471-476.

[51] Almendro, V., Busquets, S., Ametller, E., Carbó, N., Figueras, M., Fuster, G., Argilés, J.M. and López-Soriano, F.J. (2006) Effects of Interleukin-15 on Lipid Oxidation: Disposal of an Oral $\left[{ }^{14} \mathrm{C}\right]$-Triolein Load. Biochimica et Biophysica Acta, 1761, 37-42. http://dx.doi.org/10.1016/j.bbalip.2005.12.006

[52] Busquets, S., Figueras, M., Almendro, V., López-Soriano, F.J. and Argilés, J.M. (2006) Interleukin-15 Increases Glucose Uptake in Skeletal Muscle. An Antidiabetogenic Effect of the Cytokine. Biochimica et Biophysica Acta, 1760, 1613-1617. http://dx.doi.org/10.1016/j.bbagen.2006.09.001 
Scientific Research Publishing (SCIRP) is one of the largest Open Access journal publishers. It is currently publishing more than 200 open access, online, peer-reviewed journals covering a wide range of academic disciplines. SCIRP serves the worldwide academic communities and contributes to the progress and application of science with its publication.

Other selected journals from SCIRP are listed as below. Submit your manuscript to us via either submit@scirp.org or Online Submission Portal.
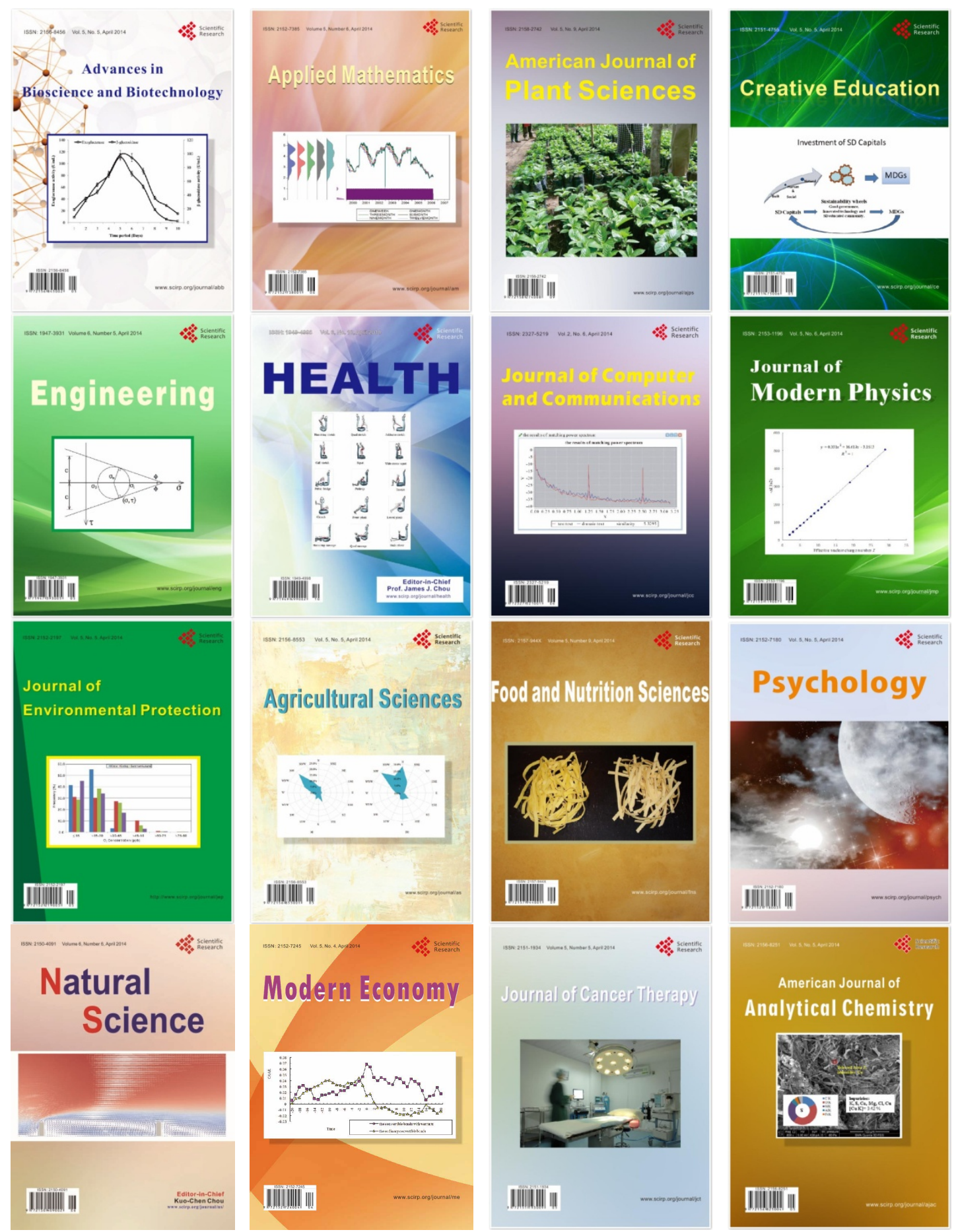